\title{
WAS ABŪ DHARR AL-GHIFĀRĪ "EXILED" TO AL-RABADHA? A Review on the Relations between Caliph 'Uthmān and Abū Dharr al-Ghifārī
}

\author{
Halil İbrahim Hançabay \\ Uludă̆ University, Bursa-Turkey
}

\begin{abstract}
The period after the Prophet Muhammad is significant in many respects. In particular, the events that took place during the time of the third caliph 'Uthmān, have a distinct importance because they had a profound impact on the future development of Islamic society. An important aspect of this period that affected political, religious, and social life during Islamic history was the relation between Caliph 'Uthmān and Abū Dharr, which resulted in Abū Dharr going to alRabadha. There are significant differences in the narratives related to these events. In some accounts, Abū Dharr went to al-Rabadha on his own request, whereas in others, he was sent into exile by the Caliph 'Uthmān because he protested his regime for corruption. This article aims to examine the relations between Caliph Uthmān and Abū Dharr in three steps: Abū Dharr's leaving to Damascus; the events that occurred between Abū Dharr and Mu'āwiya; Abū Dharr's coming back to Medina and then leaving (or being exiled) to al-Rabadha.
\end{abstract}

Key Words: Caliph 'Uthmān, Abū Dharr, al-Rabadha, exile, fitna

Historians generally divide Caliph 'Uthmān's reign (644-656) into six "good" years and six "bad" years. The events from around the year 30/650-651 which occurred in the second six-year term are significant in many respects because they had a profound impact on the future development of Islamic society. In particular the events that took 
place between Caliph 'Uthmān (d. 35/656) and Abū Dharr (d. 32/653) and that resulted in Abū Dharr going to al-Rabadha ${ }^{1}$ deserve consideration. First, it should be noted that there are significant differences between the narratives related to these events. However, it is accepted by historians that Abū Dharr went to al-Rabadha due to criticism, but at first sight it seems unclear whether he went upon his own request or was sent into exile by the Caliph. According to some narratives, the reason he was sent to al-Rabadha as an exile was that he expressed criticism toward Caliph 'Uthmān because he changed the Sunna of the Prophet and the policy of the previous two caliphs, and because of his donation from bayt al-māl to his close relatives. In addition Abū Dharr criticized Muslims who were hoarding wealth. In the narratives of the exile it is argued that some prominent șa $\bar{a} b a$ such as 'Alī ibn Abī Ṭālib (d. 40/661) and 'Abd al-Raḥmān ibn 'Awf (d. 32/652) criticized Caliph 'Uthmān due to his attitude towards Abū Dharr. According to the other narratives Abū Dharr came to Medina from Damascus, then left to al-Rabadha on his own request.

\section{I}

In the historical sources there are two different groups of narratives of Abū Dharr's arrival to Damascus. According to the first group by Ibn 'Asākir (d. 571/1176), Abū Dharr was residing in Medina. He had come to this region (Bilād al-Shäm) to participate in the conquest of Palestine, and he met Caliph 'Umar in Jābiya. ${ }^{2}$ He subsequently went to Damascus. ${ }^{3}$ The second group of accounts says that,

Al-Rabadha was a village located a three day distance from the Iraqi side of Medina; see Abū 'Abd Allāh Shihāb al-Dīn ibn 'Abd Allāh Yāqūt al-Ḥamawī, Mu'jam al-buldān (Beirut: Dār Ṣādir, 1977), III, 24.

2 Jābiya, a city eighty kilometers south of Damascus, is situated in Jawlān, not far from the site of modern Nawā. It was used as an administrative center in the time of the Ghassānids. In Islamic period, it was conquered during the time of Caliph Abū Bakr (d. 13/634) and became a military base (jund) of this region. The importance of Jābiya increased during the time of Caliph 'Umar (d. 23/644) and he visited there to decide upon conditions in the new conquests. A meeting of the generals and principal officers was held there and has remained famous wih the name yawm al-Jābiya; see Henri Lammens and J. Sourdel-Thomine, "al-Djābiya," The Encyclopaedia of Islam Second Edition, II, 360; Mustafa Fayda, "Câbiye," Türkiye Diyanet Vakfi İslâm Ansiklopedisi (DİA), VI, 538.

3 Abū l-Qāsim Thiqat al-Dīn 'Alī ibn al-Ḥasan ibn Hibat Allāh Ibn 'Asākir, Tārīkh madīnat Dimashq (ed. Muhịb al-Dīn Abū Sa'īd 'Umar ibn Gharāma al-'Amrawī; Beirut: Dār al-Fikr, 1996), LXVI, 174; also see Abū l-Fidā' 'Imād al-Dīn Ismācīl ibn 
Caliph 'Uthmān had sent Abū Dharr to Damascus a second time. There are three different narratives. According to the first narrative by al-Balādhurī (d. 279/892-893), Abū Dharr settled in Damascus where his $m a k t a b^{4}$ was and in the time of the pilgrimage he came to Medina. However after the pilgrimage he did not return to Damascus and began to live in Medina. When he saw that the buildings reached to Sal ${ }^{5}$ he asked 'Uthmān for permission to leave Medina for Damascus. ${ }^{6}$ According to the second narrative Caliph 'Uthmān heard that Abū Dharr said "'Uthmān has changed the Sunna of the Prophet and the policy of the previous two caliphs." Because of this, he sent him as an exile to Damascus, near Mu'āwiya. ${ }^{7}$ According to the third narrative quoted by al-Mas'ūdì (d. 345/956), Abū Dharr went to Damascus,

'Umar Ibn Kathīr, al-Bidāya wa-l-nihāya (Beirut: Maktabat al-Macārif, 1966), VII, 165. In the historical sources, any information is not provided about Abū Dharr's life in the time between the death of the Prophet and the end of the caliphate of Abū Bakr. As for the time of Caliph 'Umar, according to Ibn 'Abd al-Hakam who rests on the dīwān records, Abū Dharr was present at Heliopolis, $19 \mathrm{AH}$, and at Alexandria, $21 \mathrm{AH}$. In the same year he was posted to the garrison at al-Fusțāt; see Abū 1-Qāsim 'Abd al-Raḥmān ibn 'Abd Allāh Ibn 'Abd al-Ḥakam al-Mișrī, Kitāb futūh Miṣr wa-akbbāruhā (ed. Charles C. Torrey; Leiden: Brill, 1920), 94, 130, and 284. In the following years Abū Dharr and his nephew, 'Abd al-Allāh ibn al-Ṣāmit, attended to the army commanded by Mu'āwiya which conquered Amorium in $23 \mathrm{AH}$ and Cyprus in $28 \mathrm{AH}$. See Abū l-'Abbās Aḥmad ibn Yahyāa ibn Jābir al-Balādhurī, Futūḅ al-buldān (ed. 'Abd Allāh Anīs al-Ṭabbā'; Beirut: Mu’assasat al-Ma‘ārif, 1987), 210-211; Abū Ja'far Muhammad ibn Jarīr al-Ṭabarī, Tārīkh alTabarì (Tārīkh al-rusul wa-l-mulūk) (ed. Muhammad Abū l-Faḍl Ibrāhīm; $2^{\text {nd }}$ edn., Cairo: Dār al-Ma'ārif, 1967), IV, 241; The History of al-Ṭabarī: An Annotated Translation, vol. XIV: The Conquest of Iran A.D. 641-643/A.H. 21-23 (translated into English and annotated by G. Rex Smith; Albany, NY: State University of New York Press, 1994), 164.

Abū Dharr was recorded at Dīwān al-Shām.

5 Sal' is a hill on the outskirts of Medina; see Yāqūt al-Hamawī, Mu'jam, III, 240241. Al-Maqdisī called that place Sayf; see Abū Nașr al-Muțahhar ibn Țāhir alMaqdisī, Kitāb al-bad' wa-l-tārīkh (ed. Clément Huart; Baghdad: Maktabat alMuthannā, n.d.), V, 94-95.

6 Al-Balādhurī, Ansāb al-ashrāf (ed. S. D. F. Goitein; Jerusalem: The Hebrew University Press, 1936), 52-53.

7 Abū l-'Abbās Aḥmad ibn Abī Ya'qūb Isḥāq ibn Jacfar ibn Wahb ibn Wāḍị alYa'qūbī, Tārìkh al-Ya'qūbì (Beirut: Dār Șādir, 1960), II, 171. Della Vida also has argued that Abū Dharr was exiled to Syria with some of his companions; see G. Levi Della Vida [R. G. Khoury], "Uthmān b. 'Affān," The Encyclopaedia of Islam Second Edition, X, 948. 
because Caliph 'Uthmān posed a question in a gathering, which $\mathrm{Ka}$ 'b al-Akhbār (d. 32/652-53) attended, asking whether anyone else has the right to the property of a person who gives alms. Ka'b expressed the opinion that no one had has this right. The Caliph posed another question asking whether it is lawful to spend funds from bayt al-māl for themselves. Kab replied that there is nothing wrong with that. Abū Dharr became enraged because of these responses and struck his chest while raising his stick. His words are recorded: "Oh son of a Jew! What leads you to talk about our religion?" 'Uthmān who was uncomfortable due to these words reacted against him and said "Oh Abū Dharr! How much are you paining us? Get out of my sight." Because of the Caliph's attitude, Abū Dharr left for Damascus. ${ }^{8}$

Considering these narratives, it is clear that Abū Dharr joined the conquests in Syria and, after some time, returned to Medina for pilgrimage. He stayed in Medina for a while and when he saw that the buildings in Medina reached the foot of Sal', he asked 'Uthmān for permission to leave Medina for Damascus because the Prophet had told him to do so.? In fact, according to the account that is mentioned in al-Mustadrak and accepted as authentic (șąīh), Umm Dharr, Abū Dharr's wife, said that 'Uthmān did not exile Abū Dharr; rather he left Medina and went to Damascus on the advice of the Prophet. ${ }^{10}$ Furthermore after Abū Dharr came to Medina from Damascus, he asked

8 Abū 1-Hasan 'Alī ibn Ḥusayn ibn 'Alī al-Mas'ūdī, Murūj al-dhahab wa-ma'ādin al-jawhar (ed. Muḥammad Muḥȳi al-Dīn 'Abd al-Ḥamīd; Beirut: Dār al-Fikr, 1973), II, 348-349.

9 Also Rihan says, Abū Dharr spent his time mostly in Syria and in Egypt under the Caliphate of 'Umar (13-23 AH). He came back for a short period to Medina on 'Uthmān's accession to power. He, however, did not remain there for long and asked the caliph to let him to go to Damascus. See Mohammad Rihan, The Politics and Culture of an Umayyad Tribe: Conflict and Factionalism in the Early Islamic Period (London \& New York, NY: I. B. Tauris, 2014), 147-148.

10 For the word of the Prophet that Abū Dharr would leave Medina; see Abū 'Abd Allāh Muḥammad ibn 'Abd Allāh ibn Mụ̣ammad al-Ḥākim al-Nīsābūrī, alMustadrak 'alā l-Ṣaḥ̄hayn (ed. Abū 'Abd al-Raḥmān Muqbil ibn Hādī al-Wādic̄ī; Cairo: Dār al-Haramayn, 1997), III, 420; also see Abū 'Abd Allāh Muhammad ibn Aḥmad ibn 'Uthmān al-Dhahabī, Tārīkh al-Islām wa-wafayāt al-mashāhīr wa-la ‘ām (ed. 'Umar 'Abd al-Salām al-Tadmurī; Beirut: Dār al-Kitāb al-'Arabī, 1987), III ('Ahd al-khulafā’ al-rāshidīn: Ḥawādith wa-wafayāt 11-40H.), 412. 
permission from the Caliph for the same reason and went to alRabadha. ${ }^{11}$

\section{II}

After Abū Dharr returned from Medina to Damascus, he criticized Mu'āwiya as well as the Muslims who hoarded surplus wealth and did not spend it in the way of Allah. In his criticisms he recited a verse (34) from sūrat al-Tawba as evidence. ${ }^{12}$ His views attracted attention from poor people and those who opposed the government. Therefore an opposition movement began against the government and the rich. After this Abū Dharr fell out with Mu'āwiya. Historical sources provide narratives about Mu'āwiya sending Abū Dharr from Damascus to Medina. Al-Ṭabarī (d. 310/923) said that many things have been recorded about why he sent him into exile and most of which he is unwilling to mention. After making this statement, al-Ṭabarī cited an account by Sayf ibn 'Umar. Accordingly, when 'Abd Allāh ibn Saba ${ }^{13}$ came to Damascus he met ${ }^{14}$ Abū Dharr and said, "Abū

11 Al-Ṭabarī, Tārīkh, IV, 284; The History of al-Ṭabari An Annotated Translation, vol. XV: The Crisis of the Early Caliphate, The Reign of 'Uthmān A.D. 644656/A.H 24-35 (translated into English and annotated by R. Stephen Humphreys; Albany, NY: State University of New York Press, 1990), 66; Abū Zayd 'Abd alRaḥmān ibn Muhammad Ibn Khaldūn, Tārīkh Ibn Khaldūn al-musammā Dīwān al-mubtada' wa-l-khabar fì tārīkh al-'Arab wa-l-Barbar wa-man 'āșarabum min dhawī l-sha'n al-akbar (eds. Khalīl Shihạda and Suhayl Zakkār; Beirut: Dār al-Fikr, 2000), II, 588.

12 "O you, who believe! Lo! Many of the (Jewish) rabbis and the (Christian) monks devout the wealth of mankind wantonly and debar (men) from the way of Allah. They who hoard up gold and silver and spend it not in the way of Allah, unto them give tidings (O Muhammad) of a painful doom." According to al-Tabarī, this verse is both of particular and of general application. It is of particular application to those Muslims who do not pay the poor-rate on their property and to Jews and Christians who are infidels; see al-Ṭabarī, Jâmī' al-bayān 'an ta'wìl ây al-Qur'ān (Beirut: Dār al-Fikr, 1984), IX, 117-122. Al-Rāzī however, as Cameron says, mentioned three cases: this verse alludes to rabbis and monks, b) to those Muslims who were niggardly with regard to the poor-rate, and c) to all those who hoarded wealth and did not produce the imposts whether they were rabbis, monks, or Muslims; see Abū 'Abd Allāh Fakhr al-Dīn Muḥammad ibn 'Umar al-Rāzī, Tafsìr al-Fakhr al-Rāzì al-mushahbar bi-l-Tafsìr al-kabìr wa-Mafätīh al-ghayb (Beirut: Dār al-Kutub al-'Ilmiyya, 1990), XVI, 36; also see Alan John Cameron, Abû Dharr al-Ghifârî: An Examination of His Image in the Hagiography of Islam (London: Royal Asiatic Society, 1982), 73-74.

13 'Abd Allāh ibn Saba' also was called Ibn al-Sawdā', Ibn Harb, and Ibn Wahb. 
Dharr, are you surprised by Mu'āwiya saying the public money is God's property ( $a l-m \bar{a} l m \bar{a} l$ Allāh)? ${ }^{15}$ No doubt, everything belongs

However, it is not clear whether he was a real personality. Sayf ibn 'Umar, one of al-Tabarī's sources, was the chief authority for Ibn Saba's political activity against Caliph 'Uthmān; see M. G. Hodgson, "'Abd Allāh b. Saba'," The Encyclopaedia of Islam Second Edition, I, 51. Without entering debates on the historical existence of 'Abd Allāh ibn Saba', I refer to Yūsuf al-'Ishsh's substantial findings on the main narratives related to the events of fitna which occurred in the time of Caliph 'Uthmān and 'Alī. The reports regarding these events have reached us mainly through three narrators, Abū Mikhnaf, al-Wāqidī, and Sayf ibn 'Umar. Although these three narrators transmitted the same events, there are significant differences in their reports. In addition they have been criticized by mubaddithūn. Because of this, al-'Tshsh says that these narratives must be compared with other reliable reports that mention the same events to decide which is true. For this purpose he identified three reports narrated by eyewitnesses of the events. These reports belong to Abū Usayd al-Anșārī's mawlā Abū Są̄̄id, Aḥnaf ibn Qays, and Abū Khunays Sahm al-Azdī. Finally, he compared these reports with three other narratives and concluded that the narratives by Sayf ibn 'Umar point in the same direction of these three reliable reports. For more information see Yūsuf al-'Ishsh, alDawla al-Umawiyya wa-l-aḅdāth allatī sabaqathā wa-mabhadat lahā ibtidāan min fitnat 'Uthmān ( ${ }^{\text {nd }}$ edn., Damascus: Dār al-Fikr, 1985), 33-40, 65 ff. It must be noted that some scholars who consider the differences between the historical narratives and hadiths, state that Sayf is an authority and $i m \bar{a} m$ on history; see alDhahabī, Mìzān al-ítidāl fì naqd al-rijāl (ed. 'Alī Muḥammad al-Bijāwī; Beirut: Dār al-Ma'rifa, 1963), II, 255; Abū 1-Fạ̣l Shihāb al-Dīn Aḥmad ibn 'Alī Ibn Hajar al-'Asqalānī, Taqrīb al-Tahdhīb (ed. 'Abd al-Wahhāb 'Abd al-Lațif; $2^{\text {nd }}$ edn., Beirut: Dār al-Ma'rifa, 1975), I, 344. Also see Fayda, "Seyf b. Ömer," Türkiye Diyanet Vakfi İslâm Ansiklopedisi (DIA), XXXVII, 37.

14 Ethem Ruhi Fı̆̆lalı argues that 'Abd Allāh ibn Saba' did not meet with Abū Dharr because Abū Dharr died in 31/651 or 32/652 in al-Rabadha. Ibn Saba' appeared in 32/653 or 33/654. In that case, how could 'Abd Allāh ibn Saba' meet with Abū Dharr? See Ethem Ruhi Fiğlalı, "The Problem of Abd-Allah Ibn-Saba," Íslam İimleri Enstitüsü Dergisi 5 (1982), 385-386.

15 Wilferd Madelung has connected, as Sean W. Anthony states, the term māl Allāb with the caliphal title khalifat Alläb; see Madelung, The Succession to Muhammad: A Study of the Early Caliphate (New York, NY: Cambridge University Press, 1997), 84. Anthony criticizes two aspects of Madelung's argument. The first one is that this term is redolent of the events that occurred in al-Küfa, particularly Sa'īd ibn al-'Āṣ' declaration of Sawād and 'Uthmān's expression to 'Abd Allāh ibn Mas'ūd about bayt al-māl. The second is that this articulation of $m \bar{a} l$ Allāh, which is attributed to Ibn al-Sawdā', appears only in Sayf's narrative about Abū Dharr; see Sean W. Anthony, The Caliph and the Heretic: Ibn Saba' and the Origins of Shīism (Leiden \& Boston: Brill, 2012), 56, also fn. 130. Madelung's 
to God. But he intends to seize it for himself by the exclusion of Muslims and to delete the Muslims' names from the fiscal registers." Abū Dharr came to Mu'âwiya and said, "What leads you to use the term 'God's property' for the public money of the Muslims?" Mu'āwiya responded "God be merciful to you Abū Dharr. Are we not God's slaves, the public money His property, the created world His creation and public authority His authority?" Abū Dharr said, "Do not use this expression." Mu'āwiya said "Indeed, I do not say that the public money does not belong to God, but I shall call it "the property of the Muslims." After that Abū Dharr continued to warn the rich to aid the poor people and said "There will be branding irons from a fire to those who treasure up gold and silver and do not expend them in the way of God, and with this iron their foreheads, sides, and backs shall be branded." Because of his words, the poor people were angry at the rich and they remained in a difficult situation. The rich people who were uncomfortable, came to Mu'āwiya and reported their discomforts. Mu'āwiya reported to 'Uthmān that Abū Dharr rendered him helpless. 'Uthmān wrote to him in response: "Verily, dissension (fitna) has protruded its snout and eyes and poised to jump. Do not scrape the scab, but rather dispatch Abū Dharr to me. Send a guide along with him, give him adequate provisions, and treat him gently. Restrain the people and yourself as far as you can, for you will keep control of affairs only so long as you keep control of yourself." Thus, Mu'āwiya sent Abū Dharr with a guide to Medina. ${ }^{16}$

claim is difficult to accept because it refers to the very early period. On the other hand, Anthony as well uses arguments that concern two events that occurred in al-Kūfa in the very early period. Furthermore his first argument seems to be a farfetched comment.

16 Al-Ṭabarī, Târīkh, IV, 283-284; The History of al-Ṭabarì, XV, 64-65; also see Abū 1Hasan 'Izz al-Dīn 'Alī ibn Muhammad ibn 'Abd al-Karìm Ibn al-Athīr, al-Kāmil fì l-tārīkh (ed. C. Johannes Tornberg; Beirut: Dār Ṣādir, 1965), III, 114-115. Hishām Ja'ịt argues, without justification, that this narrative by Sayf ibn 'Umar cannot be accepted; see his al-Fitna: Jadaliyyat al-dìn wa-l-siyāsa fì l-Islām al-mubakkir ( $4^{\text {th }}$ edn., Beirut: Dār al-Ṭalī'a, 2000), 75, fn. 1. Mahmut Kelpetin evaluated this narrative in a different way and criticized Sayf ibn 'Umar by arguing that in this narrative it is meant to be explained that Abū Dharr in point of fact did not think about the subject like this. Abū Dharr influenced by 'Abd Allāh ibn Saba', criticized first Mu'āwiya and then Caliph 'Uthmān. In continuation of his remark, Kelpetin claimed that the reason that impelled Sayf to such a depiction was that Abū Dharr had been exiled; see his Hulefâ-yi Râşidîn Dönemi Taribi: Seyf $b$. Ömer ve Tarihçiliği (Istanbul: Siyer Yayınları, 2012), 250. However, Ahmet Güzel 
Before addressing the events that occurred after Abū Dharr had arrived in Medina, I will note other narratives that mentioned different events that caused him to be sent to Medina. Mu'āwiya built a palace in Damascus, which was called al-Khadrā'. Abū Dharr criticized him by saying that if it was built with public money it was betrayal and if it was built with his own money it was a waste. His criticism against Mu'āwiya continued. Habīb ibn Maslama ${ }^{17}$ (d. 42/662) came to Mu'āwiya and informed him that Abū Dharr was inciting the populace of Damascus against him. He recommended that $\mathrm{Mu} \overline{\mathrm{a}}$ wiya exile Abū Dharr and his family if necessary. Mu'āwiya wrote a letter to 'Uthmān and said that he wanted to dispatch Abū Dharr to Medina. 'Uthmān accepted his offer and ordered Mu'āwiya to convey him to Medina [in contrast to the previous narrative] on the roughest mount. ${ }^{18}$ It was also reported by al-Ya'qūbī (d. 292/905) that Abū Dharr was sent to Medina for another reason. Abū Dharr used to sit in the mosque and went on to make the previously reported statements. People crowded around in growing numbers to hear him. Furthermore he stood at the door of Damascus when he prayed the morning

claimed that it was not reasonable that 'Abd Allāh ibn Saba' inculcated Abū Dharr on Mu'āwiya. Abū Dharr was one of the first Muslims, hence further explanation is needed that he was carried away by the incitement of 'Abd Allāh ibn Saba'; see his "Muâviye ve Hz. Osman'a Muhalefeti Ekseninde Ebû Zerr el-Ğı̂â̂,," Marife 12/3 (2012), 60. If the one-sentence speech between Abū Dharr and Ibn Saba' in the first part of the narrative and the main discussion between Abū Dharr and Mu'āwiya on the sabab al-nuzūl of the verse (34) from sūrat al-Tawba are taken into account, however, it is clear that Abū Dharr has a distinctive opinion about kanz and infāq. Therefore it is rather difficult to talk about the incitement or the effect of Ibn Saba' on Abū Dharr. Hence, it could be said that Abū Dharr encountered Ibn Saba' who told him about some practices of Mu'āwiya which he was unfamiliar. After that he went to Mucāwiya and argued with him over this. Any other claim would be a forced interpretation of the narrative.

17 Habīb ibn Maslama, born in Mecca in 610 or 620 AD, was a companion of the Prophet. He joined the conquest of Syria and distinguished himself in the fights against the Byzantines. By order of Mu'āwiya, he conquered Armenia in 22/642. He was one of the persons who Mu'āwiya consulted, and was a brave commander. After 'Uthmān's death, he supported Mu'āwiya against 'Alī. He was appointed as a governor of Armenia in 41/661 and died there in 42/662; see Asri Çubukçu, "Habîb b. Mesleme," Türkiye Diyanet Vakfi İslâm Ansiklopedisi (DİA), XIV, 372373. Fück has argued that he was not a companion of the Prophet; see J. W. Fück, "Habīb b. Maslama," The Encyclopaedia of Islam Second Edition, III, 12.

18 Al-Balādhurī, Ansāb, V, 53; also see Abū Muhammad Ahmad Ibn A'tham al-Kūfī, Kitāb al-futū 
prayer and said: "The train carrying the fire came. God may curse those who advise good but they themselves avoid it, and those who desist others from evil but they themselves act upon it." Mu'āwiya wrote to "Uthmān, saying, "You have incited Damascus against yourself through Abū Dharr." 'Uthmān wrote back telling him to set Abū Dharr on a packsaddle without a cover and send him to Medina. ${ }^{19}$

When Abū Dharr reached Medina, he entered 'Uthmān's presence, and 'Uthmān said "O Abū Dharr, why are the Syrians complaining about your sharp tongue?" Abū Dharr described what had happened. 'Uthmān explained his policy of not forcing people to be ascetics, rather he was required to invoke them to care about God's commandments and to follow the path of moderation. Abū Dharr then asked permission to leave Medina. 'Uthmān replied that if he wanted, he could stay in a place close to there. But Abu Dharr said that the Prophet commanded him to leave Medina when the buildings reached Sal'. 'Uthmān replied that it would be good to do as the Prophet commanded him. Abū Dharr settled in al-Rabadha and Caliph 'Uthmān gave him a small herd of camels and two slaves, and instructed him to come to Medina occasionally to avoid getting used to the customs of Bedouins. ${ }^{20}$

In the conversation mentioned above, 'Uthmān explained as a caliph his limits of power in matters of financial skill. As Ahmad Jawdat Pasha (d. 1895) says, although 'Uthmān was a caliph; he did not have

\section{Al-Ya'qūbī, Tārīkh, II, 171-172.}

20 Al-Ṭabarī, Tārīkh, IV, 284; The History of al-Ṭabarī, XV, 65-66; also see Ibn alAthīr, al-Kāmil, III, 115. Keaney has argued that this narrative is the typical Sayf account in which 'Uthmān is portrayed as an ideal ruler, responding promptly and wisely to complaints in the provinces and trying to find a just solution. In continuation of her remark, she claims "Sayf thus brings a fad $\bar{a}^{\prime} i l$ sensibility of 'Uthmān and key companions to bear on issues of political policy. While the ruler is not shown exercising religious authority, there is no tension in Sayf between politics and piety, between secular and sacred authority. While this was the ideal believed to have been modeled by Muhammad, by the third/ninth century, the situation in practice was very different." See Heather N. Keaney, Medieval Islamic Historiography: Remembering Rebellion (New York, NY: Routledge, 2013), 38. Keaney's approach, which attempts to interpret Sayf's account on the basis of two modern concepts, secular and sacred, is disputable because it is unfeasible to evaluate the early era of Islamic history with such concepts, particularly, if there is no hint of religious and political distinction in the state administration. Additionally, there is no doubt that this point of view would bring about anachronism. 
the authority to distribute the surplus wealth that was in the hands of the rich Muslims giving their alms. Because they gave their alms, they could acquire possessions. ${ }^{21}$

In the historical sources other accounts were also narrated about Abū Dharr going to al-Rabadha on his own request. The reliable account on this subject is reported by Zayd ibn Wahb (d. 83/702). According to this narrative, Zayd ibn Wahb went through al-Rabadha and encountered Abū Dharr. He asked what had moved him to settle there and Abū Dharr replied that when he was in Damascus, he recited a verse (34) from sūrat al-Tawba. Mu'āwiya argued that it did not concern Muslims but rather Jews and Christians. However Abū Dharr declared that it was revealed concerning Muslims as well as Jews and Christians. Mu'āwiya then wrote to 'Uthmān complaining about him, so the Caliph wrote to Abū Dharr to come to Medina. When Abū Dharr arrived in Medina, the people gathered around him as if they had never seen him before. Abū Dharr explained to 'Uthmān what had happened between him and Mu'āwiya. Upon this, 'Uthmān told him that if he so wished he could relocate to a spot where he would be a neighbor. Zayd ibn Wahb said "That is what moved Abū Dharr to settle in al-Rabadha." At the end of the narrative Abū Dharr says that if an Abyssinian were to be invested with authority he would hear and obey him. ${ }^{22}$ Ibn Hajar, the commentator of al-Bukhārī, said of the narrative by Zayd ibn Wahb that although 'Uthmān had wanted Abū Dharr to leave Medina out of fear of the spread of fitna, Abū Dharr went to al-Rabadha on his own request. ${ }^{23}$ Al-Qasțallānī, another shāriḩ of al-Bukhārī, said that some people condemned 'Uthmān because he sent Abū Dharr into exile. Zayd ibn Wahb asked Abū Dharr about this matter and Abū Dharr explained what happened. Accordingly, al-Qasțallānī mentioned that Mu'āwiya's soldiers tended to Abū Dharr, and that Mu'āwiya was afraid of conflict between the Muslims. 'Uthmān also feared the people of Medina as much as

21 Ahmad Jawdat Pasha, Kısas-ı Enbiyâ ve Tevârib-i Hulefâ (Istanbul: Bedir Yayınevi, 1966), I, 455; also see Âdem Apak, Hz. Osman Dönemi Devlet Siyaseti (Istanbul: İnsan Yayınlar1, 2003), 156.

22 Al-Bukhārī, "Zakāt," 4; also see Abū 'Abd Allāh Muḥammad ibn Sa`d ibn Manī‘ alZuhrī, al-Ṭabaqāt al-kubrāa (ed. Iḥsān 'Abbās; Beirut: Dār Ṣādir, 1957-1968), IV, 226; al-Ṭabarī, Jāmī ‘ al-bayān, X, 121-122; Ibn 'Asākir, Tārīkh, LXVI, 198.

23 Ibn Hajar al-`Asqalānī, Fatḥ al-bārī bi-sharh Șaḥị̣ al-Bukhārī (ed. Muhammad Fu’ād 'Abd al-Bāqī et al.; Cairo: Dār al-Ma'rifa, n.d.), III, 274. 
Mu'āwiya had feared the people of Damascus. Because of this, Abū Dharr went to al-Rabadha on his own choice. ${ }^{24}$

Although there are alternative narratives mentioned by al-Ya'qūbī, al-Balādhurī, Ibn A'tham, and al-Mas'ūdì that have many irreconcilable contrasts with the account by Zayd ibn Wahb al-Juhanī, the latter should be superior to others in terms of three aspects: (1) Zayd ibn Wahb is an eyewitness and one of the main sources of these events. Because he met with Abū Dharr in al-Rabadha and talked with him about the matter, then narrated what occurred between Abū Dharr and Caliph 'Uthmān and why and how Abū Dharr came to Medina and then departed from Medina to al-Rabadha. (2) There are other reliable accounts that have parallels with Zayd's account. For instance, according to the narrative by Muhammad ibn Sīrīn, ${ }^{25}$ after Abū Dharr came to Medina, he warned 'Uthmān as he had warned Mu'āwiya in Damascus. However, when Abū Dharr saw that 'Uthmān did not incline to him, he went to al-Rabadha on his own request, and $\mathrm{Mu}$ āwiya sent his household after him. ${ }^{26}$ It is also narrated by 'Abd al-Allāh ibn al-Ṣāmit, ${ }^{27}$ Abū Dharr's nephew, that Abū Dharr himself asked 'Uthmān to allow him stay in al-Rabadha. ${ }^{28}$ Ibn Shabba (d. 262/876) mentioned that al-Hasan al-Bașrī (d. 110/728) was asked if Abū Dharr was exiled by 'Uthmān, and he replied "No, God forbid!

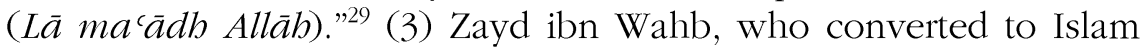
during the lifetime of the Prophet (although he never met him), was prominent among the täbicūn (successors). He has been accepted as thiqa (trustworthy) and reported many hadiths from some of the

24 Abū 1-'Abbās Shihāb al-Dīn Aḥmad ibn Muḥammad al-Qasțallānī, Irshād al-sārī li-sharh Șaḥịh al-Bukhārī (Būlāq: al-Mațba'a al-Maymaniyya, 1304 H.), III, 12.

25 Muḥammad ibn Sīrin, mawlā of Anas ibn Mālik, has been accepted as thiqa (trustworthy). He had narrated from some of the șahāba such as Abū Hurayra and 'Abd Allāh ibn 'Umar. Al-Sha'bī and Qatāda also narrated from him; see Ibn Sa'd, al-Ṭabaqāt al-kubrā, VII, 193; Abū 'Abd Allāh Muḥammad ibn Ismācīl alBukhārī, al-Tārīkh al-kabīr (Beirut: Dār al-Kutub al-'Tlmiyya, 1986), I, 90.

26 Al-Ṭabarī, Tārīkh, IV, 284-285; The History of al-Ṭabarì, XV, 67.

27 He is from the tābic'ùn and has been accepted as thiqa; see al-Bukhārī, al-Tärīkh al-kabìr, V, 118; al-cijlī, Ma'rifat al-thiqāt, II, 38.

28 Ibn Sa'd, al-Ṭabaqāt al-kubrā, IV, 232.

29 Abū Zayd 'Umar ibn Shabba al-Numayrī al-Bașrī, Tārīkh al-Madīna almunawwara (ed. Fahīm Muhammad Shaltūt; Jeddah: Dār al-Iṣfahānī, 1979), III, 1037; also see Ibn al-Athīr, al-Kāmil, III, 115. 
șahāāo such as 'Umar ibn al-Khațāāb, 'Uthmān ibn 'Affān, and 'Alī ibn Abī Ṭālib. ${ }^{30}$

This account by Zayd ibn Wahb is also accepted as reliable by modern scholars. For instance, Cameron mentions that the earliest available and reliable account on this subject is narrated by Zayd ibn Wahb, who tells us, quite briefly, that Abū Dharr settled in alRabadha because of a difference of opinion with Mu'āwiya on the interpretation of verse 34 of sūrat al-Tawba. ${ }^{31}$ Cameron also explained his contention that Abū Dharr's controversy was with the whole class of those who secularized the theocracy of Islam and that due to the failure of his preaching he withdrew from Damascus to Medina and thence to al-Rabadha. ${ }^{32}$ According to Amhiazun, this narrative is the most reliable account among those about Abū Dharr going to alRabadha. ${ }^{33}$ Considering this narrative, Yiğit states that Abū Dharr had been sent by Caliph 'Uthmān to al-Rabadha on his own request. ${ }^{34}$ However, Aydınlı argues that Caliph 'Uthmān chose al-Rabadha, because of its solitude and because some acquaintances of Abū Dharr were living there. It cannot be determined, however, who made this decision about Abū Dharr going to al-Rabadha. ${ }^{35}$

In contrast to the narratives above, there are some accounts about Abū Dharr being sent by Caliph 'Uthmān to al-Rabadha as an exile. According to the narrative by al-Ya'qūbī, when Abū Dharr arrived in

30 Ibn Sacd, al-Ṭabaqāt al-kubrā, VI, 102-103; al-Bukhārī, al-Tārīkh al-kabīr, III, 407; Abū 1-Ḥasan Aḥmad ibn 'Abd Allāh ibn Șāliḥ al-Tjilī, Ma'rifat al-thiqāt min rijāl abl al-'ilm wa-l-ḥadith wa-min al-du'afa' wa-dhikr madhāhibibim waakbbāribim (ed. 'Abd al-'Alīm 'Abd al-'Ażīm al-Bastawī; Medina: Maktabat alDār, 1985), I, 379.

Cameron, Abû Dharr al-Ghifârî, 64, 66.

Ibid., 115.

Muḥammad Amḥazūn, Taḥqīq mawāqif al-ṣaḥāba fì l-fitna min riwāyāt alImām al-Ṭabarì wa-l-muḩaddithīn (Cairo: Dār al-Salām, 2007), 330.

34 İsmail Yiğit, "Osman," Türkiye Diyanet Vakfi İslâm Ansiklopedisi (DİA), XXXIII, 438; also see Khalīl Ibrāhīm Jāsim, "Abū Dharr al-Ghifārī: Jadaliyyat al-dhāt wa-lmujtama'," Majallat al-Majma' al-'Ilmī al-'Trāqī51/3 (2004), 205.

35 Abdullah Aydınlı, "Ebû Zer el-Gıfârî," Türkiye Diyanet Vakfi İslâm Ansiklopedisi (DIA), X, 267. Jobson, without making any preference, has indicated that Abū Dharr retired or was sent to al-Rabadha where he died in 32/652-653 or 31; see J. Jobson, "Abū Dharr al-Ghifārī," The Encyclopaedia of Islam Second Edition, I, 114. The opinion of Güzel, however, is similar to that of Aydınli; he argues that al-Rabadha was chosen by Abū Dharr; see "Muâviye ve Hz. Osman'a Muhalefeti Ekseninde Ebū Zerr al-Ğıfârî," 52-54. 
Medina, he said that the Prophet Muhammad, in warning the people of the malicious rule of the Umayyads, said, "When the children of Abū 1-'Āṣ reach the number of thirty, they make the Islamic treasury as their own and the servants of God as their slaves." 'Uthmān said that he had heard that Abū Dharr narrated this hadith. Abū Dharr replied that he heard the Prophet saying it. Upon this, 'Uthmān asked 'Alī ibn Abī Țālib whether he had heard the Prophet say what Abū Dharr narrated. 'Alī replied in the affirmative and said that according to the word of the Prophet, greenery ( $\left.a l-k h a d r \bar{a}^{\prime}\right)$ never shaded and earth never bore a man more upright than Abū Dharr. After this conversation Abū Dharr stayed a few days in Medina until 'Uthmān commanded him to leave Medina. Upon this, Abu Dharr asked the Caliph whether he would expel him from the sacred city of the Prophet. 'Uthmān replied that he would. So, Abū Dharr countered by saying that he would go to Mecca. The Caliph rejected this, and Abū Dharr said "To al-Bașra." However "Uthmān replied "No," so he said "To al-Kūfa." Again "Uthmān did not accept and replied, "I send you to al-Rabadha where you came from and where you will die." He then commanded his cousin Marwān to take him off. ${ }^{36}$

36 Al-Ya'qūbī, Tārīkh, II, 171-172; also see al-Balādhurī, Ansāb, V, 54; Ibn A`tham, Kitāb al-futūh, I, 374-375; al-Mas'ūdī, Murūj al-dhahab, II, 349-350. This narrative related to the Umayyads is mentioned in some sources. Al-Dhahabi said that it was munqati`(disconnected); see al-Ḥ̄ākim al-Nīsābūrī, al-Mustadrak, IV, 647. Cameron associates Abū Dharr's request to go to al-Kūfa with 'Alī's residence there; see Abû Dharr al-Ghifârî, 87. In some narratives, it is said that Abū Dharr was subjected to ill-treatment by Marwān and a quarrel occurred between 'Alī ibn Abī Țālib and Marwān. Accordingly, 'Uthmān told Marwān to lead Abū Dharr away and ordered him not to let him talk to anyone. After they left there, 'Ali ibn Abī Ṭālib and his two sons as well as 'Abd Allāh ibn Ja'far and 'Ammār ibn Yāsir went out with him. Abū Dharr went up to 'Alī, kissed his hand and wept, saying that when he saw him and his son, he was reminded of the saying of the Prophet, and that he could not be patient and wept. 'Alì also spoke to him, but Marwān tried to prevent him by saying that the Commander of the Faithful had forbidden anyone to speak to Abū Dharr. Thereupon 'Alī raised his whip and struck Marwān's camel in the face saying "Get out of my sight! May God cast you into the fire!" Then 'Alī escorted Abū Dharr. Because of this matter, the relations between 'Uthmān and 'Alī became strained; see al-Ya'qūbī, Tārīkh, II, 171-172; alBalādhurī, Ansāb, V, 54; Ibn A'tham, Kitāb al-futūh, I, 376; al-Mas'ūdī, Murūj aldhahab, II, 350. Vaglieri, based on this narrative, has argued that when Abu Dharr was exiled from Medina because of 'Alī's salutation to Abū Dharr in spite of 'Uthmān's prohibition, a violent dispute occurred between 'Alī and 'Uthmān; 
As Milhim rightly argues, this narrative reflects al-Ya'qūbī's negative approach against Caliph 'Uthman and the Umayyads. Al-Ya'qūbī tried to confirm the word of the Prophet about the Umayyads, which he based on Abū Dharr, with the badith in which the Prophet praises Abu Dharr. ${ }^{37}$ In this point it should be kept in mind that a number of reports were narrated both in favor of the Umayyads and against them, and that most of them were fabricated due to political events. ${ }^{38}$

It is also said that when Abū Dharr reached Medina, he began criticizing 'Uthmān because he appointed some people in governmental affairs, who did not reach the age of maturity, ${ }^{39}$ because of his establishment of state land ( $\mathrm{bim} \bar{a})^{40}$ and because of creation of close ties with al-tulaq $\bar{a} \cdot{ }^{\text {.11 }}$ Due to his criticism, 'Uthmān ordered him to leave the city. Thereupon Abū Dharr said, "To Mecca." 'Uthmān replied, "No". So he said, "To Jerusalem." Again "Uthmān did not accept. So Abū Dharr said "To one of two cities [al-Kūfa or al-Bașra]." "Uthmān

see L. Veccia Vaglieri, “Alī b. Abī Țālib," The Encyclopaedia of Islam Second Edition, I, 382. It is clear in this narrative that 'Alì has been presented as a person who opposed Caliph 'Uthmān. Therefore these and similar narratives were clearly produced as a result of the efforts to bring 'Alī against 'Uthmān.

37 'Adnān Muḥammad Milhịm, al-Mu'arrikhūn al-'Arab wa-l-fitna al-kubrā (Beirut: Dār al-Ṭalī́a, 1998), 128.

38 For further information concerning this kind of narratives, see İrfan Aycan, Saltanata Giden Yolda Muaviye bin Ebî Süfyan (Ankara: Ankara Okulu Yayınları, 2001), 34-45; also see Apak, Hz. Osman Dönemi Devlet Siyaseti, 156.

39 The reason of Abū Dharr's criticism was that although Marwān was under age, 'Uthmān appointed him as kātib. Thus when he was the Caliph's kātib, he should be in his twenties; see Aycan, "Mervân I," Türkiye Diyanet Vakfi İslâm Ansiklopedisi (DIA), XXIX, 225.

40 The bim $\bar{a}$ is the land that is open to everyone for grazing of animals, and that is prohibited to appropriate of property; see Abū l-Hasan 'Alī ibn Muhammad ibn Habīb al-Māwardī, al-Aḅkām al-sulțāniyya wa-l-wilāyāt al-dīniyya (ed. Aḥmad Mubārak al-Baghdādī; Kuwait: Dār Ibn Qutayba, 1989), 242. The institution dates back to the pre-Islamic Arab society. To protect their flocks from the ill-effects of drought, the powerful nomadic lords used to reserve to themselves the grazing and watering rights in certain rich pasturages. For more information see J. Chelhod, "Himā," The Encyclopaedia of Islam Second Edition, III, 393; Mustafa Demirci, İslamın Ilk Üç Asrında Toprak Sistemi (Istanbul: Kitabevi Yayınları, 2003), 174-186.

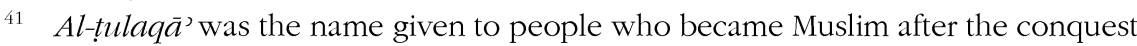
of Mecca and were not treated as captives; see Abū l-Faḍl Ibn Manẓūr ibn Mukarram Jamāl al-Dīn Muḥammad al-Anșārī al-Mișrī, Lisān al-'Arab (Beirut: Dār Ṣādir, 1955-1956), "ṭlq" s.v.; al-Ṭabarī, Tārīkh, III, 61. 
replied, "I exile you to al-Rabadha." which he eventually did. Abū Dharr lived in al-Rabadha until he died. ${ }^{42}$

Madelung argues on the basis of the narrative by al-Balādhurī that 'Uthmān ordered Abū Dharr to be sent to Medina by Mu'āwiya and, as Abū Dharr continued his 'agitation,' he was exiled to al-Rabadha in the desert. ${ }^{43}$ Balc1 has mentioned almost all narratives without making any distinction between them and asserts that the true essence of Abu Dharr going to al-Rabadha is not clear. However, he claims that according to the flow of events, Abu Dharr was forced to leave the city and he had let this decision pass unchallenged because he knew himself as a person who caused fitna. ${ }^{44}$ Jabali did not comment on other narratives, but considering the narrative by Ibn A'tham he argues that this exile was one of 'Uthmān's policies and seems to indicate that it was 'Uthmān who forced Abū Dharr to leave Medina and that it was 'Uthmān who sent him into exile outside the city. ${ }^{45}$

42 Al-Balādhurī, Ansāb, V, 52-53. It is also narrated in Ansāb al-ashrāf that when Abū Dharr came to Medina from Damascus, 'Uthmān said to him that it was better for him that they stay together than remain apart 'Uthmān also gave him some milch camels. However, Abū Dharr said that he had no need of this and he went al-Rabadha and died there.

43 Madelung mentions that the Kūfan and Bașran traditions mostly affirm that Abū Dharr was exiled by 'Uthmān against his own will. As for the Medinan tradition, it was divided into the Sunnī and the Shī $\overline{1}^{\mathrm{i}}$. According to the former, the Sunnī, Abū Dharr went voluntarily. According to the second, the Shī' $\overline{1}$ tradition, which is the tradition of al-Wāqidī, he was exiled by 'Uthmān against his will; see Madelung, The Succession to Mubammad, 84, fn. 24. Madelung has also argued that 'Uthmān mistreated Abū Dharr arrogantly as well as 'Abd Allāh ibn Mas'ūd and 'Ammār ibn Yāsir; see ibid., 87. If his relied upon account which is narrated by alBalādhurī from al-Wāqidī, is taken into consideration, it is understood that he prefers the Shīi $\overline{1}$ tradition of Medina.

44 İsrafil Balcı, "Bir Yalnız Sahabi Ebû Zer el-Gıfârî," Ondokuz Mayı Üniversitesi İlâbiyat Fakültesi Dergisi 10 (1998), 380-381.

45 Fu'ad Jabali, The Companions of The Prophet: A Study of Geographical Distribution and Political Alignments (Leiden \& Boston: Brill, 2003), 155, also fn. 93. Other scholars have argued that Abū Dharr was exiled by Caliph 'Uthmān. For instance see Fığlalı, "Ali," Türkiye Diyanet Vakfi İslâm Ansiklopedisi (DİA), II, 372; Fayda, "Hulefâ-yi Râşidîn," Türkiye Diyanet Vakfi İslâm Ansiklopedisi (DíA), XVIII, 330. 


\section{III}

Lastly, we would like to note some other narratives with doubtful reliability. These narratives note that some prominent șabāba such as 'Alī ibn Abī Ṭālib and 'Abd al-Rahmān ibn 'Awf criticized 'Uthmān due to his policy on Abū Dharr. According to a narrative by alBalādhurī, after Abū Dharr had died in al-Rabadha, 'Alī ibn Abī Ṭālib went to 'Abd al-Raḥmān ibn 'Awf and accused him by saying that he had elected 'Uthmān as a caliph. Thereupon 'Abd al-Raḥmān ibn 'Awf replied, "O 'Alī! If you want take your sword I will also take my sword. Because "Uthmān did not keep his promise he had given me." After that, he expressed his deep remorse in choosing 'Uthmān as a caliph. ${ }^{46}$

As mentioned above, after Abū Dharr died in al-Rabadha, 'Alī ibn Abī Țālib held 'Abd al-Raḥmān ibn 'Awf responsible for this event. Despite this 'Alī did not react to him when Abū Dharr was "exiled" to al-Rabadha. Therefore, a reaction of "Alī to 'Abd al-Raḥmān after two or three years is not plausible. Furthermore there is no account, except the narrative by al-Balādhurī that mentions 'Abd al-Raḥmān's criticism of 'Uthmān on Abū Dharr's death in al-Rabadha. His words, which are related to taking his sword, are narrated on other events. For instance in a narrative by Ibn $\mathrm{A}^{\mathrm{c}} \mathrm{tham}^{47}$ 'Abd al-Rahmān used the same expressions when he criticized 'Uthmān because of his donation from bayt al-māl to his close relatives. Therefore this situation casts a shadow on the reliability of this narrative. ${ }^{48}$ The existence of some accounts noting that 'Abd al-Rahmān had died earlier than Abū Dharr increases the doubts about this narrative. ${ }^{49}$

46 Al-Balādhurī, Ansāb, V, 57. In this passage 'Abd al-Rahmān ibn 'Awf allegedly refers to the question he posed to 'Uthmān before his election of caliph. In the shūrā council appointed by Caliph 'Umar, 'Abd al-Raḥmān ibn 'Awf asked, "Will you give me your oath based on the Qur'ān, the practice of his Prophet and the deeds of Abū Bakr and 'Umar." 'Uthmān replied, "Yes indeed."

47 Ibn A'tham, Kitāb al-futūh, I, 371.

48 For the narratives about Caliph 'Uthmān's donation to his close relatives and assessment of them see Milhim, al-Mu'arrikhūn al-' $\mathrm{Arab}, 96 \mathrm{ff}$.

49 According to an account by Ibn 'Asākir, Abū Dharr came to 'Uthmān one day and the inheritance that 'Abd al-Rahmān had left at his demise, was being distributed by 'Uthmān. Caliph 'Uthmān said to Ka'b al-Akhbār, "O Abū Isḥāq! Do you see the goods which are given its alms? Shall the owner ['Abd al-Rahmān] be accountable for these goods?" Kacb confirmed that which the Caliph had said. Thereupon Abū Dharr raised his stick and struck Ka'b's head while saying to him 


\section{IV}

When the accounts above are considered together, it is understood that the matter of whether Abū Dharr went to al-Rabadha on his own request or by exile is very controversial. Nonetheless three main points must be noted about the narratives regarding the matter: The first is that these accounts can be divided into three main groups: Abū Mikhnaf Lūț ibn Yạ̣yā (d. 157/773-774), Sayf ibn 'Umar (d. 180/774), and Muhammad ibn 'Umar al-Wāqidī (d. 207/823). The books of these historians, akbbäriyyün, have been largely lost but they have reached us from the next generation of historians such as al-Ya'qūbī, al-Balādhurī, and al-Ṭabarī. Here it must be noted that Sayf's accounts were narrated only by al-Ṭabarī, and that although alBalādhurī narrated from Sayf in Futū accounts about incidents of the fitna in Ansāb al-ashräf. Sayf, unlike the others, did not implicate the sabāaba in the events of fitna and defended the caliphate of 'Uthmān. Furthermore, he emphasized the unity of Islamic umma. The reason for al-Ṭabarî's choice is derived from his approach to the events; his viewpoint has parallels with that of Sayf. The best example of this can be seen in his expression "many things have been recorded as to why he sent him into exile, most of which I am loathe to mention." As for other historians, if al-Ya'qūbi who did not disclose his sources regarding the events of fitna, is excluded, al-Balādhurī, Ibn A'tham, and al-Mas'ūdī, a later historian who apparently benefited from al-Ya'qūbī and al-Balādhurī, come to the forefront. A common feature of these historians is that their accounts mainly follow the tradition of al-Wāqidī and Abū Mikhnaf who were pro-Shicite. ${ }^{51}$ This aspect is clearly understood through the ac-

"Son of a Jew! Do you think that he will not be accountable because of his goods of which he had paid its alms?" He then recited some verses to him; see Ibn 'Asākir, Tārīkh, LXVI, 197; also see Ibn Shabba, Tārīkh, III, 1036-1037; alDhahabī, Tārìkh al-Islām, 411.

50 al-Balādhurī, Futūḥ, 354, 431.

51 It is seen that the major sources of Imāmiyya rely on al-Wāqidī (i.e., the Shī'ī tradition of Medina) and al-Ya'qūbī; see Abū l-Qāsim 'Alī ibn al-Husayn ibn Mūsā ibn Muḥammad al-Sharīf al-Murtạ̣ā, al-Shāfi fi l-imāma (ed. 'Abd al-Zahrā' alHusaynī al-Khațīb; Tehran: Mu’assasat al-Ṣādiq, 1986), IV, 293-300; Jamāl al-Dīn al-Ḥasan ibn Yūsuf ibn 'Alī Ibn al-Muțahhar al-Hillī, Nabj al-ḥaqq wa-kashf alșidq (ed. 'Ayn Allāh al-Hasanī al-Urmawī; Qum: Mu’assasat Dār al-Hijra, 1986), 298-301. For the Imāmī perspective on this issue see Mehmet Salih Ar1, Imamiye Şiası Kaynaklarına Göre Ilk Üç Halife (Istanbul: Düşün Yayınc1lı, 2011), 492498. 
counts of the period of fitna, which are narrated by them. In fact, according to these narratives Abū Dharr is always represented as a $s a h a b \bar{\imath}$ protesting the "corruption" of 'Uthmān's regime and calling for a restoration of the ascetic piety and social equality of the community. It must be emphasized that a general characteristic of these accounts is that 'Alī has an important and positive role in the events, and he is reflected as a companion who supported the Caliph 'Uthmān despite his many mistakes and who interceded on Abū Dharr's behalf.

The second is that the text which Sayf provided is most coherent one. As for the other narratives, Abū Dharr was exiled to Damascus as well as al-Rabadha. However within the framework of narratives, the matter that cannot be resolved is that the same reasons ${ }^{52}$ are associated with both his exile to Damascus and to al-Rabadha. Additionally, in these accounts, different justifications have been argued about Abū Dharr's exile to al-Rabadha, so they have contradictions. Therefore this case weakens the reliability of the accounts and renders the subject incomprehensible.

The third is that some contemporary scholars, such as alGhabbān ${ }^{53}$ and Amhazūn, ${ }^{54}$ have found that the isnād of the narratives by Ibn Sacd, al-Bukhārī, and al-Ṭabarī much more reliable than others. As a result, if all of these are taken into account it is clear that Abū Dharr went to al-Rabadha on his own request.

\section{ACKNOWLEDGMENTS}

I would like to express my deepest indebtedness and gratitude to Professor İsmail Yiğit without whose critical comments and guidance this study would not have been possible.

This article was prepared within the framework of the short-term project "Ebû Zer el-Grfârî Rebeze'ye Sürüldü Mü? Hz. Osman'la Ebû Zer Arasındaki İlişkilere Yeniden Bir Bakış [Was Abū Dharr Al-Ghifārī "Exiled" to AlRabadha? A Review on Relations between Caliph 'Uthmān and Abū Dharr alGhifārīl” HDP (D)-2014/18, conducted by Âdem Apak and Halil İbrahim Hançabay, with support from Uludağ University.

52 Ibn Actham, Kitāb al-futūh, I, 375.

53 Muḥammad ibn 'Abd Allāh al-Ghabbān, Fitnat maqtal 'Uthmān ibn 'Affān (Riyadh: Maktabat al-'Ubaykān, 1999), I, $110 \mathrm{ff}$.

54 Amḥazūn, Taḅqīq mawāqif al-ṣaḥāba, 331 ff.; also see Muhammad Ṭāhir alBarzanjī, Șaḥị̣ wa-ḍa 'îf Târìkh al-Ṭabarì (Beirut: Dār Ibn Kathīr, 2007), III, 319. 


\section{REFERENCES}

Ahmad Jawdat Pasha, Kısas-ı Enbiyâ ve Tevârih-i Hulefâ, 2 vols., (Istanbul: Bedir Yayınevi, 1966).

Amḥazūn, Muhammad, Taḥqūq mawāqif al-ṣaḥāba fì l-fitna min riwāyāt alImām al-Ṭabarī wa-l-muḥaddithīn (Cairo: Dār al-Salām, 2007).

Anthony, Sean W., The Caliph and the Heretic: Ibn Saba' and the Origins of Shī ism (Leiden \& Boston: Brill, 2012).

Apak, Âdem, Hz. Osman Dönemi Devlet Siyaseti (Istanbul: İnsan Yayınlan, 2003).

Arı, Mehmet Salih, Imamiye Şiası Kaynaklarma Göre İlk Üç Halife (Istanbul: Düşün Yayınclık, 2011).

al-'Asqalānī, Abū l-Faḍl Shihāb al-Dīn Aḥmad ibn 'Alī Ibn Ḥajar, Fath al-bārī bi-sharh Șahīh al-Bukhārī, 13 vols., (ed. Muhammad Fu'ād 'Abd alBāqī et al.; Cairo: Dār al-Ma'rifa, n.d.).

Taqrīb al-Tahdhīb, 13 vols., (ed. 'Abd al-Wahhāb 'Abd al-Lațîf; $2^{\text {nd }}$ edn., Beirut: Dār al-Ma'rifa, 1975).

Aycan, İffan, Saltanata Giden Yolda Muaviye bin Ebî Süfyan (Ankara: Ankara Okulu Yayınları, 2001).

"Mervân I," Türkiye Diyanet Vakfi İslâm Ansiklopedisi (DİA), XXIX, 225-227.

Aydınlı, Abdullah, "Ebû Zer el-Gıfârî," Türkiye Diyanet Vakfi İslâm Ansiklopedisi (DIA), X, 266-269.

al-Balādhurī, Abū l-'Abbās Aḥmad ibn Yaḥyā ibn Jābir, Ansāb al-ashrāff, 5 vols., (ed. S. D. F. Goitein; Jerusalem: The Hebrew University Press, 1936).

Futūḥ al-buldān (ed. 'Abd Allāh Anīs al-Ṭabbā‘'; Beirut: Mu’assasat alMa'ārif, 1987).

Balcı, İsrafil, "Bir Yalnız Sahabi Ebû Zer el-Gıfâtr̂," Ondokuz Mayıs Üniversitesi ilâhiyat Fakültesi Dergisi 10 (1998), 351-386.

al-Barzanjī, Muhammad Țāhir, Șaḥ̣̣̄ wa-da îf Tārîkh al-Tabarī, 13 vols., (Beirut: Dār Ibn Kathīr, 2007).

al-Bukhārī, Abū 'Abd Allāh Muḥammad ibn Ismācîl, Șaḥīh al-Bukhārī, 6 vols., (Istanbul: Çağrı Yayınlanı, 1992). al-Tārīkh al-kabìr, 12 vols., (Beirut: Dār al-Kutub al-clmiyya, 1986).

Cameron, Alan John, Abû Dharr al-Ghifârî: An Examination of His Image in the Hagiography of Islam (London: Royal Asiatic Society, 1982).

Chelhod, J., "Himā," The Encyclopaedia of Islam Second Edition, III, 393.

Çubukçu, Asri, "Habîb b. Mesleme," Türkiye Diyanet Vakfi İslâm Ansiklopedisi (DİA), XIV, 372-373.

Della Vida, G. Levi [R. G. Khoury], "Uthmān b. 'Affān," The Encyclopaedia of 
Islam Second Edition, X, 946-949.

Demirci, Mustafa, İslamm İlk Üç Asrnnda Toprak Sistemi (Istanbul: Kitabevi Yayınları, 2003).

al-Dhahabī, Abū 'Abd Allāh Muhammad ibn Aḥmad ibn 'Uthmān, Mīzān al$i$ ‘tidāl fì naqd al-rijāl, 4 vols., (ed. 'Alī Muhammad al-Bijāwīi; Beirut: Dār al-Ma‘rifa, 1963).

Tārīkh al-Islām wa-wafayāt al-mashāhīr wa-l-a lām, 53 vols., (ed. 'Umar 'Abd al-Salām al-Tadmurī; Beirut: Dār al-Kitāb al-'Arabī, 1987).

Fayda, Mustafa, "Câbiye," Türkiye Diyanet Vakfi İslâm Ansiklopedisi (DIA), VI, 538.

"Hulefâ-yi Râşidîn," Türkiye Diyanet Vakfi İslâm Ansiklopedisi (DİA), XVIII, 324-338.

"Seyf b. Ömer," Türkiye Diyanet Vakfi İslâm Ansiklopedisi (DIA), XXXVII, 37.

F1ğlalı, Ethem Ruhi, "The Problem of Abd-Allah Ibn-Saba," Islam Ilimleri Enstitüsü Dergisi 5 (1982), 379-390.

"Ali," Türkiye Diyanet Vakfi İslâm Ansiklopedisi (DíA), II, 371-374.

Fück, J. W., "Habīb b. Maslama," The Encyclopaedia of Islam Second Edition, III, 12.

al-Ghabbān, Muhammad ibn 'Abd Allāh, Fitnat maqtal 'Uthmān ibn 'Affān, 2 vols., (Riyadh: Maktabat al-`Ubaykān, 1999).

Güzel, Ahmet, "Muâviye ve Hz. Osman'a Muhalefeti Ekseninde Ebû Zerr elĞıârî," Marife 12/3 (2012), 43-68.

al-Hāakim al-Nīsābūrī, Abū 'Abd Allāh Muhammad ibn 'Abd Allāh ibn Muhammad, al-Mustadrak 'alā l-Ṣaḥihayn, 5 vols., (ed. Abū 'Abd alRaḥmān Muqbil ibn Hādī al-Wādic̄i; Cairo: Dār al-Haramayn, 1997).

al-Hiillī, Jamāl al-Dīn al-Hasan ibn Yūsuf ibn 'Alī Ibn al-Muțahhar, Nahj alhaqq wa-kashf al-șidq (ed. 'Ayn Allāh al-Hasanī al-Urmawī; Qum: Mu’assasat Dār al-Hijra, 1986).

Hodgson, M. G., "'Abd Allāh b. Saba'," The Encyclopaedia of Islam Second Edition, I, 51.

Ibn 'Abd al-Hakam, Abū l-Qāsim 'Abd al-Raḥmān ibn 'Abd Allāh al-Mișrī, Kitāb futūḥ Miṣr wa-akhbāruhā (ed. Charles C. Torrey; Leiden: Brill, 1920).

Ibn al-Athīr, Abū 1-Hasan 'Izz al-Dīn 'Alī ibn Muhammad ibn 'Abd al-Karīm, alKāmil fì l-tārīkh, 13 vols., (ed. C. Johannes Tornberg; Beirut: Dār Ṣādir, 1965-1967).

Ibn 'Asākir, Abū 1-Qāsim Thiqat al-Dīn 'Alī ibn al-Hasan ibn Hibat Allāh, Târìkh madinat Dimashq, 80 vols., (ed. Muhibb al-Dīn Abū Sā̄id 'Umar ibn Gharāma al-'Amrawī; Beirut: Dār al-Fikr, 1996).

Ibn A'tham, Abū Muḥammad Aḥmad al-Kūfī, Kitāb al-futūḥ, 4 vols., (ed. 'Alī 
Shīrī; Beirut: Dār al-Ậ̣ā', 1991).

Ibn Kathīr, Abū l-Fidā' 'Imād al-Dīn Ismāc̄il ibn 'Umar, al-Bidāya wa-l-nihāya, 14 vols., (Beirut: Maktabat al-Ma‘̄àrif, 1966).

Ibn Khaldūn, Abū Zayd 'Abd al-Raḥmān ibn Muhammad, Tārīkh Ibn Khaldūn al-musammā Dīwān al-mubtada' wa-l-khabar fì tārīkh al-'Arab wa-lBarbar wa-man 'āṣarahum min dhawi l-sha'n al-akbar, 8 vols., (eds. Khalīl Shihāda and Suhayl Zakkār; Beirut: Dār al-Fikr, 2000).

Ibn Manẓūr, Abū l-Fac̣l Ibn Manẓūr ibn Mukarram Jamāl al-Dīn Muhammad alAnșārī al-Miṣrī, Lisān al-‘'Arab, 15 vols., (Beirut: Dār Ṣādir, 1955-1956).

Ibn Sa'd, Abū 'Abd Allāh Muḥammad ibn Sa'd ibn Man̄̄' al-Zuhrī, al-Ṭabaqāt al-kubrā, 9 vols., (ed. Iḥsān 'Abbās; Beirut: Dār Ṣādir, 1957-1968).

Ibn Shabba, Abū Zayd 'Umar ibn Shabba al-Numayrī al-Bașrī, Tārīkh alMadina al-munawwara, 4 vols., (ed. Fahīm Muhammad Shaltūt; Jeddah: Dār al-Ișfahānī, 1979).

al-'Tjlī, Abū 1-Hasan Aḥmad ibn 'Abd Allāh ibn Ṣālị̣, Ma'rifat al-thiqāt min rijāl abl al-'ilm wa-l-hadìth wa-min al-ḍu'afa's' wa-dhikr madhāhibihim wa-akbbāribim, 2 vols., (ed. 'Abd al-'Alīm 'Abd al-'Azịm alBastawī; Medina: Maktabat al-Dār, 1985).

al-'Ishsh, Yūsuf, al-Dawla al-Umawiyya wa-l-aḅdāth allatī sabaqathā wamahbadat labā ibtidā ${ }^{x a n}$ min fitnat 'Uthmān (2 ${ }^{\text {nd }}$ edn., Damascus: Dār al-Fikr, 1985).

Jabali, Fu'ad, The Companions of The Prophet: A Study of Geographical Distribution and Political Alignments (Leiden \& Boston: Brill, 2003).

Jaīị, Hishām, al-Fitna: Jadaliyyat al-dīn wa-l-siyāsa fì l-Islām al-mubakkir (4 ${ }^{\text {th }}$ edn., Beirut: Dār al-Ṭalī'a, 2000).

Jāsim, Khalīl Ibrāhīm, "Abū Dharr al-Ghifārī: Jadaliyyat al-dhāt wa-l-mujtamac," Majallat al-Majma' al-'Ilmì al-'Trāqī 51/3 (2004), 179-210.

Jobson, J., "Abū Dharr al-Ghifārī," The Encyclopaedia of Islam Second Edition, I, 114-115.

Keaney, Heather N., Medieval Islamic Historiography: Remembering Rebellion (New York, NY: Routledge, 2013).

Kelpetin, Mahmut, Hulefâ-yi Râşidîn Dönemi Taribi: Seyf b. Ömer ve Taribçiliği (Istanbul: Siyer Yayınları, 2012).

Lammens, Henri and Sourdel-Thomine, J., "al-Djābiya," The Encyclopaedia of Islam Second Edition, II, 360.

Madelung, Wilferd, The Succession to Muhammad: A Study of the Early Caliphate(New York, NY: Cambridge University Press, 1997).

al-Maqdisī, Abū Nașr al-Muțahhar ibn Țāhir, Kitāb al-bad' wa-l-tārīkh, 6 vols., (ed. Clément Huart; Baghdad: Maktabat al-Muthannā, n.d.).

al-Mas'ūdī, Abū l-Hasan 'Alī ibn Husayn ibn 'Alī, Murūj al-dhahab wama'ādin al-jawhar, 4 vols., (ed. Muhammad Muhyē al-Dīn 'Abd alHamīd; Beirut: Dār al-Fikr, 1973). 
al-Māwardī, Abū l-Ḥasan 'Alī ibn Muḥammad ibn Habīb, al-Aḅkām alsulțāniyya wa-l-wilāyāt al-dīniyya (ed. Aḥmad Mubārak al-Baghdādī; Kuwait: Dār Ibn Qutayba, 1989).

Milhịm, 'Adnān Muhammad, al-Mu'arrikbūn al-'Arab wa-l-fitna al-kubrā (Beirut: Dār al-Ṭalī‘a, 1998).

al-Qasțallānī, Abū l-‘Abbās Shihāb al-Dīn Aḥmad ibn Muḥammad, Irshād alsārì li-sharḥ Șạ̣ị̣ al-Bukhārī, 10 vols., (Būlāq: al-Maṭba'a alMaymaniyya, 1304 H.).

al-Rāzī, Abū 'Abd Allāh Fakhr al-Dīn Muhammad ibn 'Umar, Tafsīr al-Fakhr al-Rāzī: Al-mushabhar bi-l-Tafsīr al-kabìr wa-Mafātīh al-ghayb, 32 vols., (Beirut: Dār al-Kutub al-'Tlmiyya, 1990).

Rihan, Mohammad, The Politics and Culture of an Umayyad Tribe: Conflict and Factionalism in the Early Islamic Period (London \& New York, NY: I. B. Tauris, 2014).

al-Sharîf al-Murtạ̣ā, Abū l-Qāsim 'Alīi ibn al-Ḥusayn ibn Mūsā ibn Muhammad, al-Shāfì fì l-imāma, 4 vols., (ed. 'Abd al-Zahrā' al-Husaynī al-Khațīb; Tehran: Mu'assasat al-Ṣādiq, 1986).

al-Ṭabarī, Abū Ja'far Muhạmmad ibn Jarīr, Tārīkh al-Tabarī (Tārīkh al-rusul wa-l-mulūk), 11 vols., (ed. Muḥammad Abū l-Fạ̣l Ibrāhīm; $2^{\text {nd }}$ edn., Cairo: Dār al-Ma'ārif, 1967).

The History of al-Tabari An Annotated Translation, vol. XIV: The Conquest of Iran A.D. 641-643/A.H. 21-23 (translated into English and annotated by G. Rex Smith; Albany, NY: State University of New York Press, 1994).

The History of al-Tabari An Annotated Translation, vol. XV: The Crisis of the Early Caliphate, The Reign of 'Utbmän A.D. 644-656/A.H. 24-35 (translated into English and annotated by R. Stephen Humphreys; Albany, NY: State University of New York Press, 1990).

Vaglieri, L. Veccia, "Alī b. Abī Ṭālib," The Encyclopaedia of Islam Second Edition, I, 381-386.

al-Ya'qūbī, Abū l-'Abbās Aḥmad ibn Abī Ya'qūb Isḥāq ibn Ja‘far ibn Wahb ibn Wāụih, Tārīkh al-Ya'qūbì (Beirut: Dār Șādir, 1960).

Yāqūt al-Hamawī, Abū 'Abd Allāh Shihāb al-Dīn ibn 'Abd Allāh, Mu'jam albuldān, 5 vols., (Beirut: Dār Ṣādir, 1977).

Yiğit, İsmail, "Osman," Türkiye Diyanet Vakfi İslâm Ansiklopedisi (DİA), XXXIII, 438-443. 